\title{
In vivo rectal inflammatory mediator changes with radiotherapy to the pelvis
}

\author{
A T Cole, K Slater, $M$ Sokal, C J Hawkey
}

\begin{abstract}
In vivo changes in the rectal values of eicosanoid inflammatory mediators induced by pelvic radiotherapy were measured to study the pathophysiology of the early radiation bowel reaction. Ten patients having pelvic radiotherapy, aged 57 to 78 , had rectal dialysis. Values of the eicosanoids leukotriene $B_{4}$ $\left(\mathbf{L T B}_{4}\right)$, thromboxane $\mathrm{B}_{2}\left(\mathrm{TXB}_{2}\right)$, and prostaglandin $\mathbf{E}_{2}\left(\mathbf{P G E}_{2}\right)$ were measured before radiotherapy, at the end of radiotherapy, and at least four weeks after radiotherapy. Values of $\mathrm{LTB}_{4}$ rose with radiotherapy from 0.21 ng.ml ${ }^{-1}$ (median) to $1.14 \mathrm{ng}^{-m^{-1}}(p=0.012)$ PGE 2 rose from $0.60 \mathrm{ng} . \mathrm{ml}^{-1}$ to $1.58 \mathrm{ng} . \mathrm{ml}^{-1}$ $(p=0.038)$, and $\mathrm{TXB}_{2}$ rose from $0.365 \mathrm{ng} \cdot \mathrm{ml}^{-1}$ to $1.6 \mathrm{ng} \cdot \mathrm{ml}^{-1}(\mathrm{p}=0.005)$. The rise in eicosanoid inflammatory mediators may have an important role in the pathophysiology of the early radiation bowel reaction.

(Gut 1993; 34: 1210-1214)
\end{abstract}

The early radiation bowel reaction occurs in radiotherapy to the pelvis in up to $75 \%$ of patients treated. ${ }^{12}$ This normal tissue injury is a limiting factor for radiotherapy dose. The early reaction is associated with symptoms of diarrhoea and nausea ${ }^{3}$ and histologically is characterised by an inflammatory cell infiltrate, oedema, ulceration, epithelial cell loss, congestion, and nuclear damage. ${ }^{4}$

The cellular mechanisms underlying this reaction are not clearly understood; they probably entail the triggering of inflammatory reactions by the release of reactive species generated by ionising radiation. Eicosanoid inflammatory mediators include the oxidative products of arachidonic acid prostaglandin $\mathrm{E}_{2}\left(\mathrm{PGE}_{2}\right)$, thromboxane $\mathrm{A}_{2}\left(\mathrm{TXA}_{2}\right)$, and leukotriene $\mathrm{B}_{4}$ $\left(\mathrm{LTB}_{4}\right)$. Eicosanoid mediators of inflammation are raised in animal models of radiation injury to the gut. ${ }^{5}$

We have investigated the mechanism of the early radiation bowel reaction in vivo in humans by measuring changes in rectal dialysate values of $\mathrm{PGE}_{2}, \mathrm{LTB}_{4}$, and $\mathrm{TXB}_{4}$ (the stable product of $\mathrm{TXA}_{2}$ ).

Therapeutics, University

Hospital, Nottingham

A T Cole

C J Hawkey

Department of Clinical Oncology, General Oncology, General
Hospital, Nottingham K Slater

$M$ Sokal

Correspondence to:

Professor C J Hawkey,

Department of Therapeutics,

University Hospital

Nottingham NG7 2UH.

Accepted for publication

19 January 1993
PATIENTS

Ten patients, nine men, one women were studied; all were receiving radical pelvic irradiation for bladder or prostatic cancer. The study was approved by the Nottingham University Hospital Ethics Committee. Patients gave written informed consent. One other patient withdrew from the trial because of development of a painful rectum during radiotherapy. The study was conducted in a subregional radiotherapy centre and an academic department of gastroenterology and therapeutics.

\section{RADIOTHERAPY}

Radiotherapy was given as clinically indicated using either a $6 \mathrm{MV}$ or $8 \mathrm{MV}$ linear accelerator. The dose to the rectum was calculated from the planning computed tonography. The maximum and minimum radiation dose to the rectum was calculated in the plane of the planning slice for each patient. The dialysis technique sampled this area. Radiotherapy for cancer of the bladder was typically given in two phases; phase I tumour dose of 40 Gray in 20 daily fractions over four weeks and phase II 20 Gray in 10 daily fractions over two weeks, the different phases being distinguished by the fields used but always irradiating a similar volume of the rectum. Radiotherapy for cancer of the prostate was also in two phases but with a 25 Gray phase two, in 15 fractions.

CLINICAL SCORING OF ABDOMINAL SYMPTOMS A clinical score was derived at the time of each dialysis by adding scores for: abdominal pain (none $=0$, mild $=1$, moderate $=2$, severe $=3$ ); the stool frequency ( 1 or less per day $=0,2$ to $3=1$, 4 to $5=2,6$ to $9=3,10$ or more $=4$ ); the visible presence of blood in the stool (none $=0$, a trace $=1$, more than a trace $=2$ ); and the stool consistency (normal $=0$, semiformed $=1$, liquid=2). All medicines taken by patients were recorded.

\section{RECTAL DIALYSIS}

Patients had rectal dialysis at baseline and then at the end of the course of radiotherapy. Six patients had a third dialysis after at least a further four weeks. Rectal dialysis bags were made from $3 / 8$ inch Visking Tubing (Medicell) with a molecular weight cut off of 12000-14000 filled with Rheomacrodex (Pharmacia) as previously described. ${ }^{6}$ Patients evacuated their bowels before rectal dialysis. Dialysis bags were inserted per rectum for two hours and then removed. A two hour dialysis time does not achieve equilibrium values of the eicosanoid measured but reflects epithelial values and has been used by other authors. ${ }^{7}$ We did not discard stained dialysates. The treatment time was chosen 


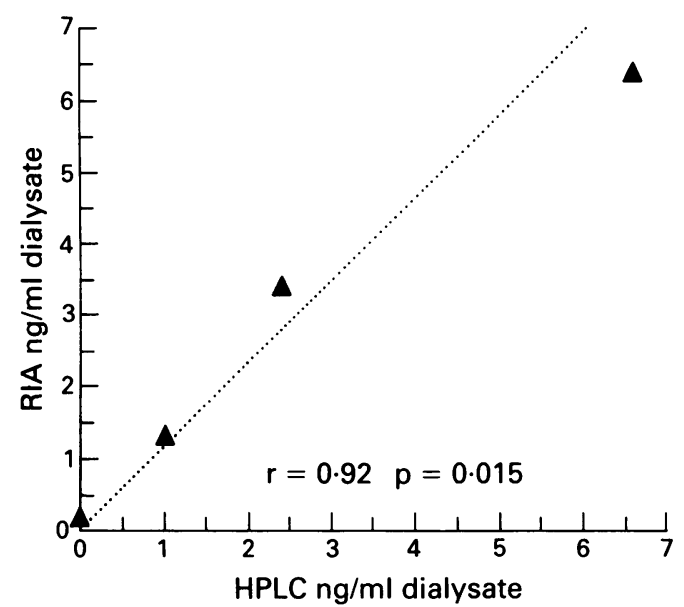

Figure 1: Correlation of radioimmunoassay and high performance liquid chromatography (HPLC) measurements of spiked dialysate $\mathrm{LTB}_{4}$.

because patients are able to tolerate it well and variable early expulsion is avoided. Dialysis was performed at the same time of day for each subject. Unextracted samples were stored at $-40^{\circ} \mathrm{C}$ and samples extracted into methanol were stored at $-20^{\circ} \mathrm{C}$. Samples from individual subjects were assayed together.

RADIOIMMUNOASSAY OF EICOSANOIDS

Dialysates were assayed by radioimmunoassay. The assays were validated against high performance liquid chromatography (HPLC) for the $\mathrm{LTB}_{4}$ assay and against gas chromatography and mass spectrometry (GCMS) for the $\mathrm{TXB}_{2}$ and $\mathrm{PGE}_{2}$ assay.

$\mathrm{LTB}_{4}$

Samples were extracted for $\mathrm{LTB}_{4}$ assay. One ml of rectal dialysate sample was mixed with $1 \mathrm{ml}$ of HPLC grade methanol (Fisons). This precipitated out the dextran which was spun down at $3500 \mathrm{rpm}$ at $4^{\circ} \mathrm{C}$ for 10 minutes. Samples of each supernatant $(1.67 \mathrm{ml})$ were taken and acidified to pH 4 with $0.5 \%$ trifluoroacetic acid (Sigma) using an autotitrator (Radiometer, Copenhagen). Fifty $\mu \mathrm{l}$ of ${ }^{3} \mathrm{H} \mathrm{LTB} \mathrm{LT}_{4}$ (approximately

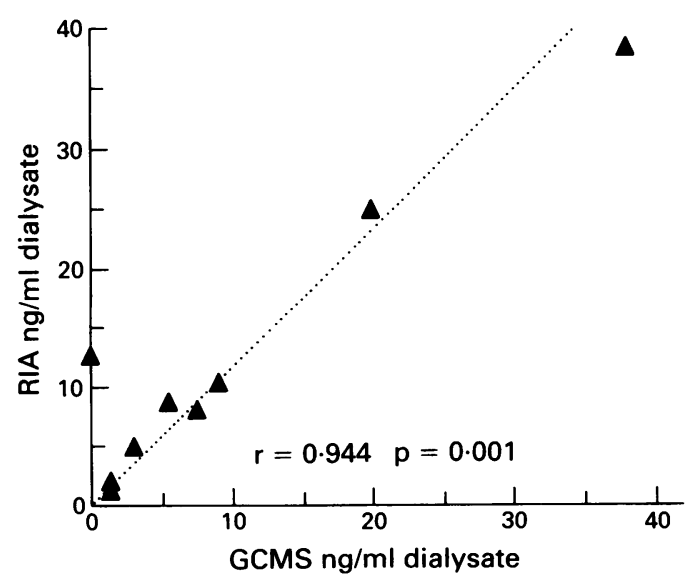

Figure 2: Correlation of radioimmunoassay and gas chromatography and mass spectrometry (GCMS) measurements of dialysate $P G E_{2}$.

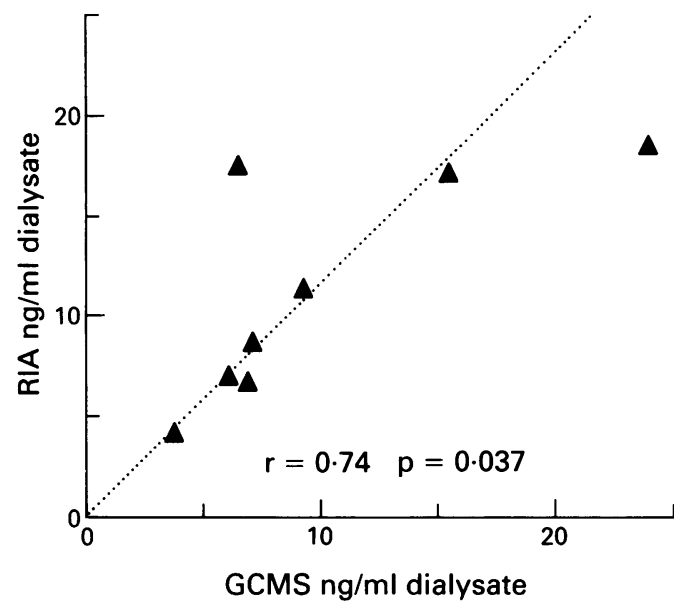

Figure 3: Correlation of radioimmunoassay and gas chromatography and mass spectrometry (GCMS) measurements of dialysate $T X B_{2}$.

$1000 \mathrm{cpm}$, Amersham International) was added as a recovery standard and the sample further diluted with $2 \mathrm{ml}$ of water at $\mathrm{Ph} 3 \cdot 5$. Each sample was loaded onto a C8 reverse phase silica cartridge with metal frits (Bond-elute, Anachem) previously prepared with washes of methanol and water at $\mathrm{pH} 3.5$; washed with $1 \mathrm{ml}$ each of HPLC grade water, $10 \%$ ethanol and hexane, and finally eluted with $1 \mathrm{ml}$ of methanol.' Extracted samples were stored in sealed polypropylene tubes at $-20^{\circ} \mathrm{C}$ and subsequently assayed with a commercial radioimmunoassay (Amersham International). The assay has a cross reactivity for $20-\mathrm{OH} \mathrm{LTB}_{4}$ of $3 \cdot 9 \%$, with lower cross reactivity to other eicosanoids. Samples were measured in comparison with extracted standards prepared in duplicate.

$\mathrm{PGE}_{2}$ AND TXB 2

$\mathrm{PGE}_{2}$ and $\mathrm{TXB}_{2}$ were assayed in diluted unextracted dialysates by radioimmunoassay as previously described. ${ }^{10}$ The $\mathrm{PGE}_{2}$ antibody (Sigma) has a cross reactivity of $51 \%$ to $P E_{1}$ but not to other eicosanoids. $\mathrm{TXB}_{2}$ antibody was obtained from Levine." The antibody has a cross reactivity of $<1 \%$ to $\mathrm{PGE}_{2}$ and other eicosanoids."

VALIDATION OF RADIOIMMUNOASSAYS

Healthy volunteer dialysate spiked with 1-5 ng.ml $\mathrm{LTB}_{4}$ was assayed by both HPLC and radioimmunoassay. Results correlated well $(\mathrm{r}=$ $0.92, p=0.015)($ Fig 1). Dialysates from patients with ulcerative colitis were assayed both by GCMS and by radioimmunoassays. For $\mathrm{PGE}_{2}$ (Fig 2) and $\mathrm{TXB}_{2}$ (Fig 3), there was a good correlation for both radioimmunoassays: $\mathrm{PGE}_{2}$ $(\mathrm{r}=0.944, \mathrm{p}=0.001)$ and $\mathrm{TXB}_{2}(\mathrm{r}=0.736, \mathrm{p}=$ $0.037)$. In spiking experiments $10 \mathrm{ng} \cdot \mathrm{ml}^{-1}$ of $\mathrm{LTB}_{4}, \mathrm{PGE}_{2}$, and $\mathrm{TXB}_{2}$ were added to $\mathrm{n}=6$ samples. Separate unspiked aliquots of the same dialysate were also assayed. The measured differences were not significantly different from the known addition: $\mathrm{LTB}_{\mathbf{4}} \mathbf{8 8} \%$ recovery (confidence intervals, $73-103 \%) ; \mathrm{TXB}_{2} \quad 108 \%$ recovery $(82-134 \%) ; \mathrm{PGE}_{2}$ recovery $112 \%(91-$ $113 \%)$. 
TABLE Details of patients

\begin{tabular}{|c|c|c|c|c|c|c|c|}
\hline \multirow[b]{2}{*}{ Age } & \multirow{2}{*}{$\begin{array}{l}\text { Diagnostic } \\
\text { group }\end{array}$} & \multicolumn{2}{|c|}{ Radiotherapy } & \multicolumn{2}{|c|}{ Clinical score } & \multicolumn{2}{|c|}{$\begin{array}{l}\text { Opiate and anti-diarrhoeal } \\
\text { medicines }\end{array}$} \\
\hline & & $\operatorname{Max}$ & $\operatorname{Min}$ & Before & After & Before & After \\
\hline 78 & B & $32 \cdot 2$ & $19 \cdot 8$ & 0 & 0 & & \\
\hline 62 & B & 46.8 & $31 \cdot 2$ & 0 & 0 & & Loperamide \\
\hline 57 & $\bar{P}$ & $64 \cdot 3$ & $50 \cdot 3$ & 2 & 2 & & \\
\hline 78 & B & $50 \cdot 5$ & $18 \cdot 0$ & 1 & 5 & & Codeine \\
\hline 74 & B & $60 \cdot 4$ & $21 \cdot 8$ & 2 & 2 & & Coproxamol \\
\hline 64 & B & $59 \cdot 8$ & $23 \cdot 0$ & 0 & 1 & & Dihydrocodeine \\
\hline 74 & B & $51 \cdot 6$ & $32 \cdot 0$ & 0 & 2 & & \\
\hline 75 & B & $60 \cdot 0$ & $21 \cdot 4$ & 2 & 3 & & \\
\hline 66 & $\mathrm{P}$ & $45 \cdot 2$ & $24 \cdot 4$ & 4 & 5 & & $\begin{array}{l}\text { Coproxamol } \\
\text { Loperamide }\end{array}$ \\
\hline 74 & B & $61 \cdot 2$ & $36 \cdot 2$ & 0 & 4 & Coproxamol & \\
\hline
\end{tabular}

$\mathrm{B}=$ bladder cancer, $\mathrm{P}=$ prostate cancer. Radiotherapy = calculated total dose in planning slice in $\mathrm{Gy}$ $(\max =$ maximum dose, $\min =$ minimum dose $)$. Before $=$ baseline before treatment; After $=$ at end of radiation treatment.

\section{SENSITIVITY}

Sensitivity was assessed as the threshold detection at $90 \% \mathrm{~B} / \mathrm{Bo}$ for the individual radioimmunoassays. The $\mathrm{LTB}_{4}$ assay threshold was $0 \cdot 2$ ng. $\mathrm{ml}^{-1}$ dialysate at the strongest dilution used for assay ( 1 in 4$)$. The $\mathrm{TXB}_{2}$ assay threshold was $0.1 \mathrm{ng} \cdot \mathrm{ml}^{-1}$ and the $\mathrm{PGE}_{2}$ assay threshold was $0.6 \mathrm{ng} \cdot \mathrm{ml}^{-1}$.

\section{REPRODUCIBILITY OF ASSAYS}

Paired specimens were measured in the same assay. The intra assay variability of $\mathrm{LTB}_{4}$ at $2 \cdot 46$ ng. $\mathrm{ml}^{-1}$ showed a standard deviation of 0.5 ng. $\mathrm{ml}^{-1}$, coefficient of variation $20 \cdot 13 \%$. $\mathrm{PGE}_{2}$ assay showed an intra assay variability at 8.8 ng. $\mathrm{ml}^{-1}$ of standard deviation $0.92 \mathrm{ng} \cdot \mathrm{ml}^{-1}$, coefficient of variation $11 \cdot 5 \%$. $\mathrm{TXB}_{2}$ assay had an intra assay variability at mean $6 \cdot 55 \mathrm{ng} . \mathrm{ml}^{-1}$ of

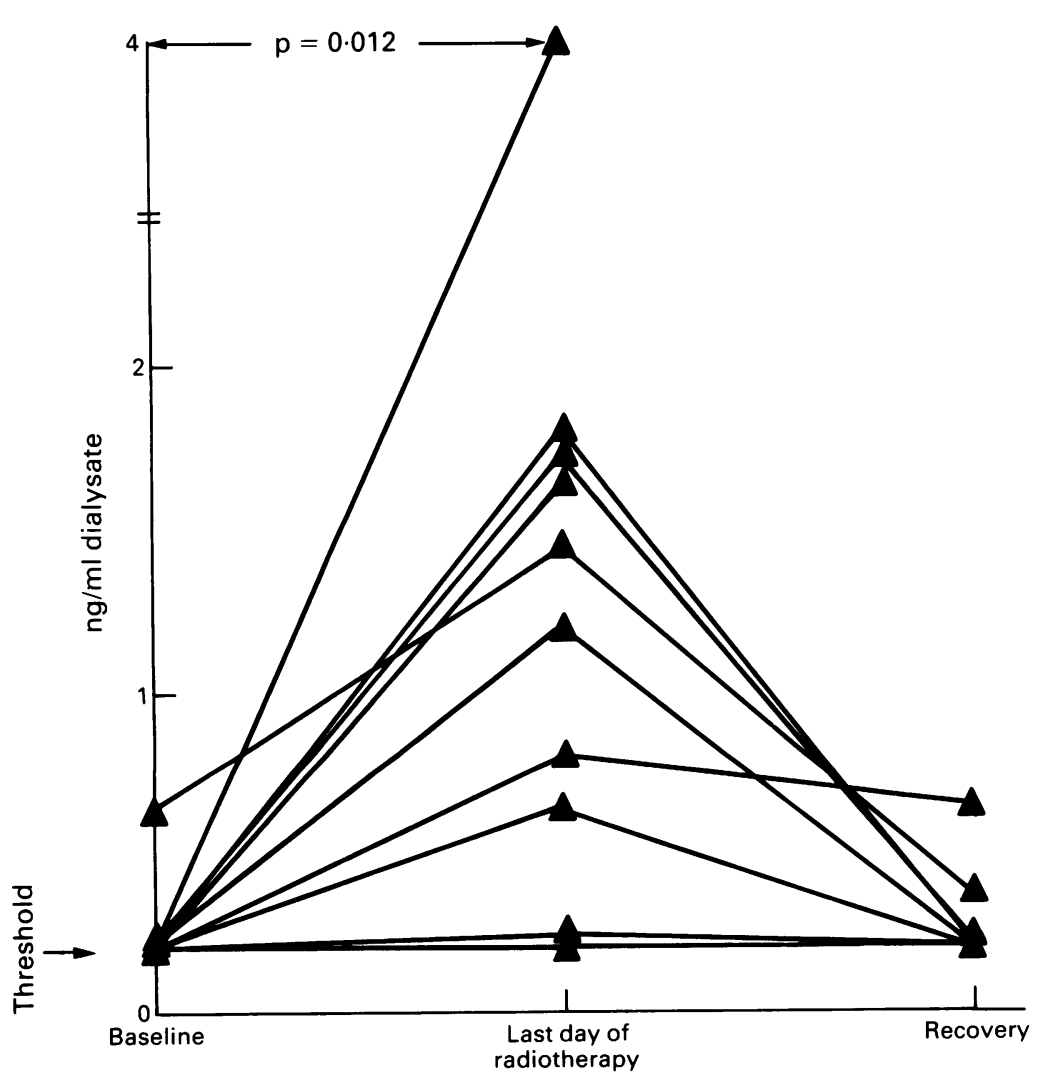

Figure 4: Effect of radiotherapy on values of $L T B_{4}$ in rectal dialysis.
$0 \cdot 26 \mathrm{ng} \cdot \mathrm{ml}^{-1}$ standard deviation, coefficient of variation $4 \cdot 01 \%$.

\section{FAECAL COLORATION OF DIALYSATES}

Coloration of the dialysates was assessed as light absorbency at $488 \mathrm{~nm}$ measured by spectrophotometry (Pye Unicam) (stained dialysates typically have a broad peak at this frequency).

\section{STATISTICAL ANALYSIS}

The Wilcoxon signed rank test for matched pairs was used for statistical analysis.

\section{Results}

\section{RADIATION DOSE TO THE RECTUM}

The Table shows the dose ranges for the individual patients. The minimum dose given to the rectum in the plane of the radiotherapy planning slice ranged from 18 to $50 \cdot 3 \mathrm{~Gy}$ and the maximum dose ranged from $32 \cdot 2$ to $64 \cdot 3$ Gy.

CHANGES IN CLINICAL SCORES AND DRUG USAGE The Table shows the drugs given and clinical scoring. Six of the patients used an opiate or an anti-diarrhoeal preparation during the radiotherapy. Clinical scoring rose by 1 (median, 0 to 4) points. There tended to be a correlation between the clinical score at the end of radiotherapy and the values of $\mathrm{PGE}_{2}(\mathrm{r}=0.49, \mathrm{p}=$ 0.076 Spearman), $\mathrm{TXB}_{2}(\mathrm{r}=0.47, \mathrm{p}=0.085)$, and $\mathrm{LTB}_{4}(\mathrm{r}=0 \cdot 37, \mathrm{p}=0 \cdot 15)$.

\section{CHANGES IN DIALYSATE COLORATION}

The colour of the dialysate was not significantly different between the three dialysis periods changing from an absorbency of 0.56 (median, range 0.2 to 4.56$)$ at baseline to $1 \cdot 1(0.36$ to $7 \cdot 52$, difference $\mathrm{p}=0.37$ Wilcoxon) after radiotherapy and to $1.09(0.08$ to 5.06 , difference from post radiotherapy dialysis $p=0 \cdot 12$ ) four weeks after radiotherapy.

CHANGES IN INFLAMMATORY MEDIATORS AFTER RADIOTHERAPY

Radiotherapy caused rectal eicosanoid value to rise. The finish of radiotherapy caused values to fall back towards baseline after four weeks. Figure 4 shows the results for $\mathrm{LTB}_{4}$. There is a consistent and significant rise in the $\mathrm{LTB}_{4}$ from 0.21 (median, range 0.20 to 0.64 ) before radiotherapy to $1 \cdot 14(0 \cdot 20$ to $4 \cdot 0)$ after radiotherapy (median rise $0.89 \mathrm{ng} . \mathrm{ml}^{-1}, \mathrm{p}=0.012$ ). In those subjects studied again at four to eight weeks after radiotherapy $\mathrm{LTB}_{4}$ values fell by $1 \mathrm{ng} \cdot \mathrm{ml}^{-1}$ ( 0 to $-1 \cdot 6, p=0 \cdot 028)$.

$\mathrm{TXB}_{2}$ rose after radiotherapy from 0.36 ng. $\mathrm{ml}^{-1}(0 \cdot 10$ to $0 \cdot 88)$ before radiotherapy to $1 \cdot 6$ $\left(0.26\right.$ to $3 \cdot 28$, (median rise $1.25 \mathrm{ng} \cdot \mathrm{ml}^{-1}(\mathrm{p}=$ $0.005)$ ) and then fell four weeks after radiotherapy stopped by $1.33 \mathrm{ng} . \mathrm{ml}^{1}$ ( +0.05 to $-3.01, \mathrm{p}=0.028)\left(\right.$ Fig 5). $\mathrm{PGE}_{2}$ rose after radiotherapy from $0.6 \mathrm{ng} . \mathrm{ml}^{-1}(0.60$ to $2 \cdot 4)$ to 1.58 
ng. $\mathrm{ml}^{-1}$ (median 0.60 to 9.6 ) with a median rise of $\left.0.44 \mathrm{ng} \cdot \mathrm{ml}^{-1}, \mathrm{p}=0.038\right)$ and then fell by $-0.48 \mathrm{ng} \cdot \mathrm{ml}^{-1}$ (median, range +0.92 to -1.56 , $\mathrm{p}=0 \cdot 173)($ Fig 6$)$.

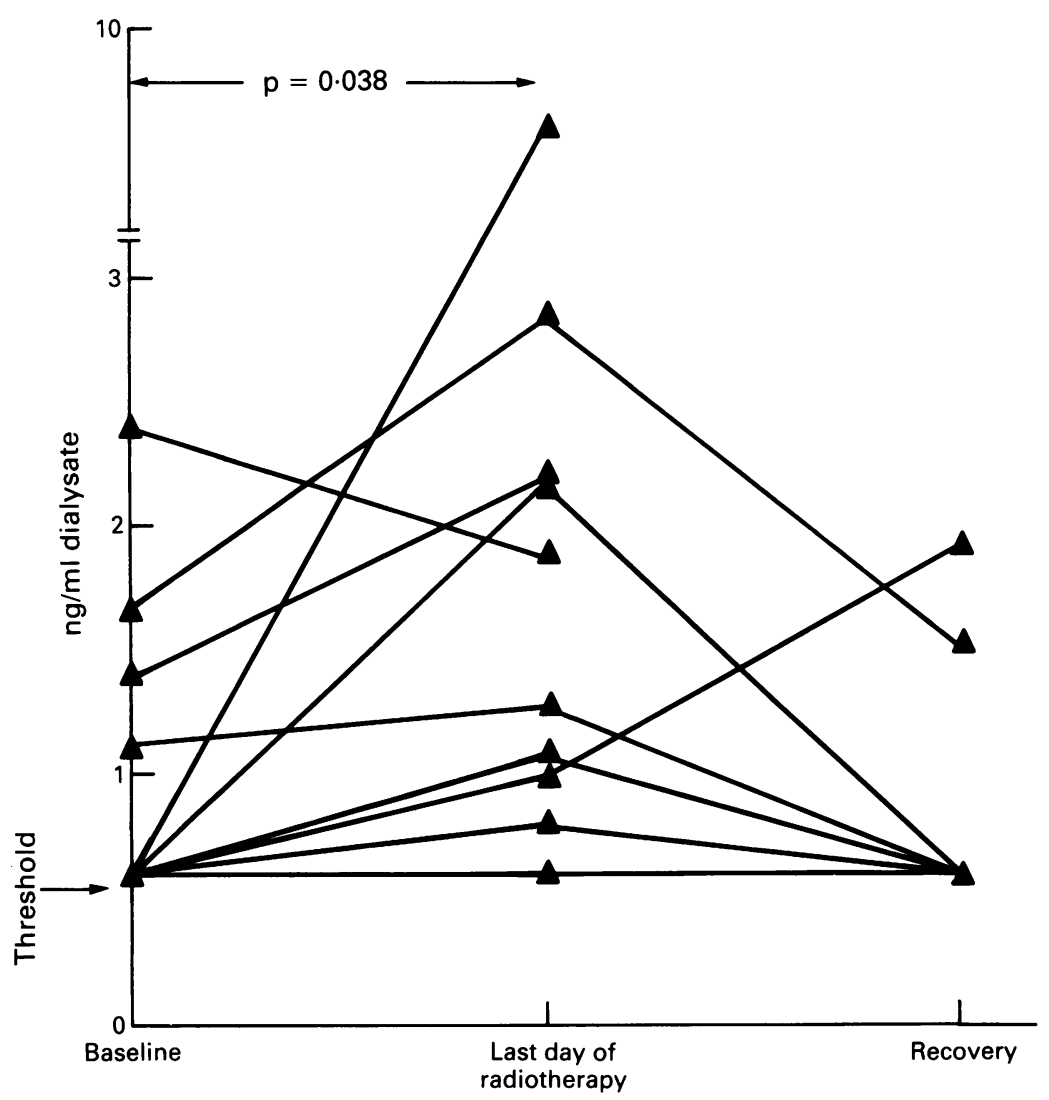

Figure 5: Effect of radiotherapy on values of $P G E_{2}$ in rectal dialysis.

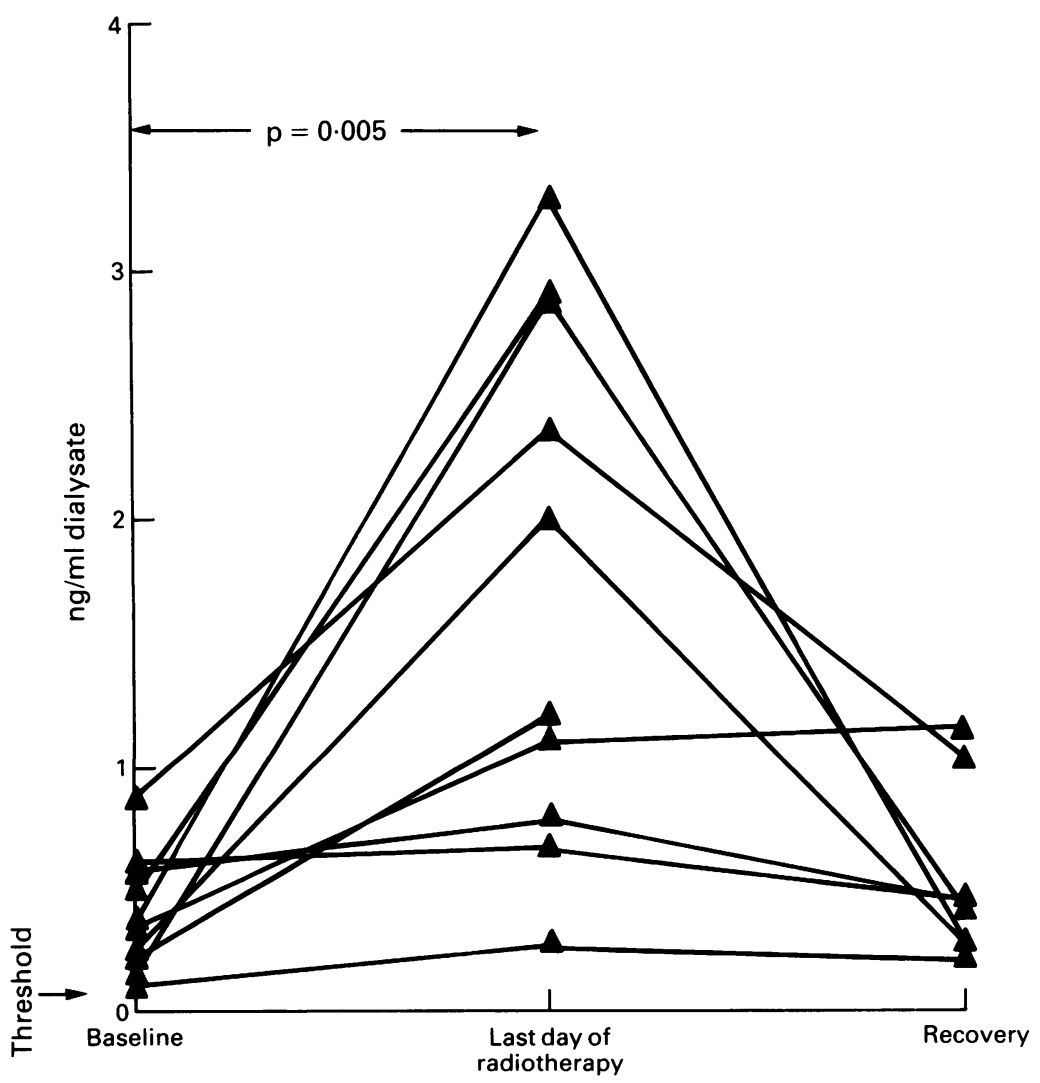

Figure 6: Effects of radiotherapy on values of $T X B_{2}$ in rectal dialysis.
Discussion

We have shown that rectal dialysate values of $\mathrm{LTB}_{4}, \mathrm{TXB}_{2}$, and $\mathrm{PGE}_{2}$ rise after pelvic radiotherapy. These mediators are probably responsible for pathological changes because it is known that these mediators can induce an inflammatory response by changing capillary permeability, inducing inflammatory cell infiltration, and activating the inflammatory cells. Leukotriene $\mathbf{B}_{4}$ causes neutrophil chemotaxis, adherence, aggregation, degranulation, and an oxidative burst. ${ }^{12}$ Thromboxane causes adherence of neutrophils and vasoconstriction. ${ }^{1314}$ Prostaglandin $\mathrm{E}_{2}$ promotes oedema formation and chloride secretion ${ }^{15}$ (however, it also has some anti-inflammatory action such as inhibiting neutrophil degranulation). The changes in mediators tended to correlate with the clinical score. This also supports the proposed pathogenical role. We did not look at the histological correlate of the inflammatory mediators as for ethical reasons we did not perform sigmoidoscopy and rectal biopsy.

The mechanism of induction of eicosanoids may be either primary or secondary. A trigger for leukotriene synthesis may be the formation by ionising radiation of lipid peroxides, which may in turn promote synthesis of leukotrienes by LTA $_{4}$ hydrolase. ${ }^{16}$ Evidence supportive of this mechanism is that vitamin $\mathrm{E}$, a fat soluble free radical scavenger, reduces the formation of fluid in a rat model of radiation enteritis. ${ }^{17}$

Other biological effects of radiation may also be important. Radiation induces nuclear regulating proteins, these are able to regulate cytokines, ${ }^{18}$ which may themselves have secondary effects on eicosanoids. Radiation damage to the epithelium ${ }^{19}{ }^{20}$ will lead to a breakdown of the mucosal barrier to chemoattractants such as FMLP, ${ }^{21}$ bacteria, and toxins, resulting in a secondary inflammatory response. Radiation may induce diarrhoea by a non- inflammatory mechanism such as bile acid malabsorption ${ }^{22}$ (although only as a feature of late radiation damage to the small bowel).

Although we did not study any patients with severe symptoms, our findings seem to be clinically relevant. Clinical scores rose in $6 / 10$ patients, anti-diarrhoeal drugs were used in $3 / 10$, and opiate containing preparation in a further three. The changes in eicosanoids reflected the clinical symptoms; and we would expect them to be greater in severely symptomatic patients. We do not know whether our findings of early changes in rectal dialysate eicosanoid values relate to the risk of late complications.

In pelvic radiotherapy the early rise in rectal leukotrienes, thromboxane, and prostaglandins has a potential treatment implication as inhibitors are available. Aspirin will inhibit both thromboxane and prostaglandin synthesis; it has been shown to ameliorate the early radiation bowel reaction. ${ }^{23}$ Steroids inhibit the synthesis of all the eicosanoids; they reduce late radiation induced fibrosis in experimental models. ${ }^{2+}$ Prostaglandins, however, may be radioprotective. ${ }^{1720}$ Therefore, selective inhibitors that inhibit leukotrienes and thromboxanes but not prostaglandins may be of value. Drugs such as 5lipoxygenase inhibitors ${ }^{25}$ and $\mathrm{TXB}_{2}$ synthase 
inhibitors and receptor antagonists ${ }^{26}$ are becoming available. Specific prophylactic inhibition of eicosanoid inflammatory mediators should be investigated as a way of limiting normal tissue injury to the rectum during pelvic radiotherapy.

The authors would like to acknowledge the help of Dr S Barrow for assistance in validation with GCMS and Dr N Entwhistle (Fisons) for assistance in HPLC validation. Parts of these data have been published in abstract form previously (Gut 1991; 32: A1205) and in: Nigram S, Honn KV, Marnett LJ, Walden Jr TL. Eicosanoids and other bioactive lipids in cancer inflammation and Eicosanoids and other bioactive lipids in cancer infle
radiation injury. Boston: Kluwer Academic, 1992.

1 Galland RB, Spence J, eds. Radiation enteritis. London: Edward Arnold, 1990

2 Gilinsky NH, Burns DG, Barbezat GO, Levin W, Myers HS Marks IN. The Natural History of Radiation-inducted Proctosigmoiditis. An Analysis of 88 Patients. $Q \mathcal{F}$ Med 1983; ??: 40-53

3 Bosch A, Frias Z. Complications after radiation therapy for cervical carcinoma. Acta Radiol Oncol Radiat Phys Biol 1977; 16: 53-62.

4 Weisbrot IM, Liber AF, Gordon BS. The effects of therapeutic irradiation on colonic mucosa. Cancer 1975; 36: 93140.

5 Harding RK, Leach KE, Prud'home-Lalonde L, Ferrarotto CL. Release of inflammatory mediators from irradiated gastrointestinal tissue. Gastroenterology 1990; 102 (suppl): A258.

6 Lauritsen K, Laursen LS, Bukhave K, Rask-Madsen J. Effects of topical 5-aminosalicylic acid and prednisolone on Effects of topical 5-aminosalicylic acid and prednisolone on
prostaglandin $E_{2}$ and leukotriene $B_{4}$ levels determined by prostaglandin $E_{2}$ and leukotriene $B_{4}$ levels determined by equilibrium in vivo dialysis of rectum in rela

7 Rampton DS, Sladen GE, Youlten LJ. Rectal mucosal prostaglandin $\mathrm{E}_{2}$ release and its relation to disease activity, electrical potential difference, and treatment in ulcerative colitis. Gut 1980; 21 : 591-6.

8 Barrow SE, Ward PS, Sleightholm MA, Ritter JM, Dollery CT. Cigarette smoking: profiles of thromboxane and prostacyclin derived products in human urine. Biochim Biophsys Acta 1989; 993: 121-7.

9 Powell WS. Rapid extraction of oxygenated metabolites of arachidonic acid from biological samples using octadecylsilyl arachidonic acid from biological samples
silica. Prostaglandins 1980; 20: 947-57.

10 Hawkey CJ, Trulove SC. Effect of prednisolone on prostaglandin synthesis by rectal mucosa in ulcerative colitis: an investigation by laminar flow bioassay and radioimmunoassay. Gut 1981; 22: 190-3
11 Alam I, Ohuchi K, Levine L. Determination of cyclooxygenase products and prostaglandin metabolites using high-pressure liquid chromatography and radioimmunoassay. Anal Biochem 1979; 93: 339-45.

12 Palmblad J, Malmsten CL, Udén AM, Rådmark ?, Engsted L, Samuelsson B. Leukotriene $B_{4}$ is a potent and stereospecific samuelsson $B$. Leukotriene $B_{4}$ is a potent and stereospecific stimulator of neutro

13 Gresele P, Deckmyn H, Nenci GG, Vermylen J. Thromboxane synthase inhibitors, thromboxane receptor antagonists and dual blockers in thrombotic disorders. Trends Pharmacol Sci 1991; 12: 158-63.

14 Goldman G, Welbourn R, Valeri CR, Shepro D, Hechtman $H B$. Thromboxane $A_{2}$ induces leukotriene $B_{4}$ synthesis that in turn mediates neutrophil diapedesis via $C D 18$ activation. Microvasc Res 1991; 41: 367-75.

15 Robert A. Prostaglandins and the gastrointestinal tract. In Johnson LR, ed. Physiology of the gastrointestinal tract. New York: Raven Press, 1991: 1407-34.

16 Haeggstrom JZ, Wetterholm A, Samuelsson B. Leukotriene $\mathrm{A}_{4}$ hydrolase: a zinc metalloenzyme with dual enzymatic $\mathrm{A}_{4}$ hydrolase: a zinc metalloenzyme with dual enzymatic $\mathrm{Jr}$, eds. Eicosanoids and other bioactive lipids in cancer inflammation and radiation injury. Boston: Kluwer Academic inflammation and

17 Empey LR, Papp JD, Jewell LDA, Fedorak RN. Mucosal protective effects of vitamin $\mathrm{E}$ and misoprostol during acute radiation induced enteritis in rats. Dig Dis Sci 1992; 37: 20514.

18 Brach MA, Hass R, Sherman ML, Gunji H, Weichselbaum R, Kufe D. Ionizing radiation induces expression and binding activity of the nuclear ractor $x \beta . \mathcal{F}$ Clin Invest 1991; 88: 691-5.

19 Bloomer WD, Hellman S. Normal tissue response to radiation therapy. NEngl F Med 1975; 293: 80-3.

20 Hanson WR, DeLaurientis K. Comparison of in vivo murine intestinal radioprotection by E-prostaglandins. Prostaglandins 1987; 33: 93-104.

21 Chadwick VS, Schlup MMT, Cooper BT, Broom MF. Enzymes degrading bacterial chemotactic F-met peptides in human ileal and colonic mucosa. $\mathcal{F}$ Gastroenterol Hepato 1990; 5: 375-81.

22 Arlow FL, Dekovich AA, Priest RJ, Beher WT. Bile acids in radiation-induced diarrhoea. South Med F 1987; 80: 125961 .

23 Mennie AT, Dalley V. Aspirin in radiation induced diarrhoea. Lancet 1973; i: 1131.

24 Evans ML, Graham MM, Mahler PA, Rasey JS. Use of steroids to suppress vascular response to radiation. Int $\mathcal{F}$ Radiat Oncol Biol Phys 1987; 13: 563-7.

25 McMillan RM, Walker ERH. Designing therapeutically effective 5-lipoxygenase inhibitors. Trends Pharmacol $S c i$ 1992; 13: 323-30.

26 Fiddler GT, Lumley P. Preliminary clinical studies with thromboxane synthase inhibitors and thromboxane receptor blockers. Circulation 1990; 81 (suppl): 169-78. 